\title{
Hyvinvointivaltio, Baumolin tauti ja väärät lääkkeet
}

\section{Elina Aaltio}

Talouspoliittisessa retoriikassa on tullut tavaksi korostaa, kuinka hyvinvointivaltion tulevaisuutta varjostaa julkisen sektorin heikko tuottavuus. Palveluiden kysynnän uskotaan kasvavan väestön ikääntyessä, ja tämä taas lisää julkisia menoja, mikäli hyvinvointipalveluiden tuottavuus ei parane. Tavaratuotannossa tuottavuus on jatkuvasti kehittynyt teknologisen kehityksen myötä. Palvelualat sen sijaan ovat työvoimaintensiivisiä, eikä niillä tuotantoa voi vastaavasti tehostaa. Ongelmana tätä pidetään siksi, että julkisen sektorin työntekijöiden palkkoja pitää kuitenkin nostaa, jotta työntekijöitä ei menetettäisi korkean tuottavuuden aloille. Tätä tuottavuuskehityksen epätasapainoa kutsutaan ns. Baumolin taudiksi. Lääkkeeksi tähän tautiin esitetään yleensä julkisen sektorin tuottavuuden parantamista. Viime aikoina on innostuttu myös julkisten tehtävien lakkauttamisista.

Samaan aikaan toisaalla sosiaalipolitiikan asiantuntijat ja palvelujen käyttäjät pitävät palveluita huonoina, riittämättöminä ja kyvyttöminä lisäämään hyvinvointia. Kritiikistä huolimatta kuntien työntekijät ja poliitikot uskovat leikkausten välttämättömyyteen. Talousasiantuntijat vetoavat kestävyysvajeen ja ylivelkaantumisen ohella Baumolin taudin kaltaisiin taloudellisiin reunaehtoihin.

Mutta mitä Baumol itse asiassa sanoi? Voiko häntä käyttää sellaisen politiikan legitimoimiseen, jonka välittöminä seurauksina näyttäisi olevan palvelujen laadun heikennyksiä, työttömyyttä, ylitöitä, palveluiden karsimista ja palveluja hakevien ulossulkemisia? Vai onko Baumolin tauti lähtenyt elämään omaa elämäänsä kyseenalaisin seurauksin?

Palataan ajassa puoli vuosisataa taaksepäin, ja katsotaan, mistä oikeastaan alun perin oli kyse. 


\section{Baumol, Bowen ja esittävän taiteen ongelma}

1960-luvun alussa riippumaton yhdysvaltalainen tutkimussäätiö The Twentieth Century Foundation (nyk. The Century Foundation) päätti käynnistää tutkimusprojektin esittävän taiteen taloudellisesta tilasta. Tutkimuksen toteuttivat Princetonin yliopiston taloustieteen professori William J. Baumol ja hänen apulaisprofessorinsa William G. Bowen.

Ironista kyllä, nykyisin ei vastaavassa tilaustutkimuksessa olisi mahdollista käyttää kuin murto-osa siitä avustajamäärästä, jota herrat professorit esipuheessaan kiittävät. Tutkimusraportti julkaistiin kahden vuoden uurastuksen jälkeen vuonna 1966 nimellä "Performing Arts - The Economic Dilemma. A Study of Problems common to Theater, Opera, Music and Dance". Tähän klassikkoon taloustieteilijöillä ja valtiovarainministeriön virkamiehillä on tapana viitata, kun julkisen sektorin tuottavuus tulee puheeksi. Politiikkasuositukset eivät kuitenkaan vastaa niitä, joita kirjassa aikanaan annettiin.

Baumolille ja Bowenille oli annettu tehtäväksi selvittää, miksi taiteilijat ja taideorganisaatiot olivat jatkuvasti taloudellisissa vaikeuksissa. Lähtökohtana oli, että taideorganisaatioiden riittämättömät tulovirrat uhkasivat esiintyjien toimeentuloa, hyvinvointia ja taideinstituutioiden olemassaoloa. Tämä puolestaan uhkasi Yhdysvaltain kulttuurielämän tulevaisuutta. Mistä taloudelliset vaikeudet johtuivat, ja mitä asialle tuli tehdä?

Julkisessa keskustelussa oli aiemmin syytetty muun muassa inflaatiota, taideorganisaatioiden huonoa johtamista ja ammattiliittojen vaatimuksia pitää töissä työntekijöitä, joiden työpanosta ei olisi tarvittu. Argumentit voisi siirtää sellaisenaan 2010-luvun sosiaalipoliittiseen keskusteluun eikä kukaan arvaisi, että ne on kaivettu kulttuuripolitiikan naftaliinista puolen vuosisadan takaa. Baumolin ja Bowenin mukaan mikään edellisistä ei kuitenkaan ollut pätevä selitys esittävän taiteen taloudellisille vaikeuksille, vaan niiden taustalla oli krooninen ongelma - alan hidas tuottavuuskehitys.

Yhdysvalloissa työn tuottavuus oli jo pitkään ollut nousussa. Teknologinen kehitys ei kuitenkaan voinut nostaa esittävän taiteen tuottavuutta samassa tahdissa. Vaikka esimerkiksi lentomatkustaminen oli pienentänyt kiertueiden matkakustannuksia, ja ilmastointi oli mahdollistanut esityskausien pidentämisen, työn luonne ei ollut vuosisatojen kuluessa juurikaan muuttunut. Esittävässä taiteessa taiteilijan työ oli lopputuote itsessään. 
Vaikka kirjoituskoneita rakennettaessa voitiin pyrkiä vähentämään sen valmistukseen tarvittavaa ihmistyötä, taiteessa tämä ei tullut kysymykseen. Yleisö osti juuri taiteilijoiden aikaa. Jos heidän koulutustaan tai harjoitusmääriään vähennettäisiin, se vain heikentäisi lopputuotteen laatua. Vaikka autoja voitiin rakentaa aiempaa nopeammin, kolme varttia kestävän Schubertin kvarteton esittämiseen tarvittiin nyt ja tulevaisuudessa kolme henkilötyötuntia.

Baumolin ja Bowenin perusidea oli yksinkertainen: talous jakautui kahteen osaan eli korkean ja matalan tuottavuuden sektoreihin. Teollisuus kuului selvästi ensimmäiseen, esittävä taide jälkimmäiseen. Teollisuudessa työntekijöiden palkkoja voitiin korottaa heidän alansa tuottavuuskehityksen tahdissa ilman, että yksikkötyökustannukset kasvoivat. Taiteessa yksikkötyökustannusten pitäminen ennallaan (eli palkankorotusten sitominen taidealan tuottavuuskehitykseen) johtaisi taiteilijoiden yhä pahenevaan köyhtymiseen. Mikäli taiteilijoiden kulutusmahdollisuuksia suhteessa tuottavan sektorin työntekijöihin ei haluttu jättää aivan täysin jälkeen, heidän palkkojaan oli nostettava huonosta tuottavuuskehityksestä huolimatta. Tämä johti väistämättä yksikkökustannusten nousuun esittävän taiteen alalla. Sama koski kaikkia matalan tuottavuuden aloja.

Baumolin ja Bowenin oma ratkaisu esittävän taiteen rahoitusongelmiin oli lisätä niiden rahoitusta. Silloin kun markkinoilta ei ollut taiteen tuottamista hyödyistä tarpeeksi rahastettavissa, valtion tuli tarjota julkista tukea. Yksikkökustannusten kasvu ja rahoitusvaikeudet eivät olleet taiteilijoiden omaa syytä, eikä muutenkaan voinut olettaa, että taidelaitokset ja -ryhmät sen enempää kuin vaikkapa oppilaitoksetkaan olisivat omavaraisia. Mikäli yhteiskunta halusi elävää taidetta tai laadukasta opetusta, yhteiskunnan tuli täyttää se tulokuilu, mikä laitosten tilinpäätöksistä puuttui.

Baumol ja Bowen olivat kulttuurin, koulutuksen ja köyhyyden vastaisen kamppailun asialla. He kirjoittivat suorasukaisesti, että mikäli valtio epäonnistui esittävän taiteen tukemisessa, se epäonnistui yhteiskunnan tarpeiden tyydyttämisessä (Baumol \& Bowen 1966, 386). Heidän nähdäkseen taide oli monella tapaa arvokasta kasvatuksen, sivistyksen ja kulttuurin kehittymisen, mutta myös kansakunnan maineen ja houkuttelevuuden kannalta. He eivät hyväksyneet näkemystä, jonka mukaan julkista rahaa ei voisi ohjata taiteeseen kiireellisempien investointikohteiden takia.

Baumolin ja Bowenin mielestä liittovaltion budjettia voitiin kasvattaa, 
jos tarpeen (mt., 371). He eivät myöskään hyväksyneet väitettä, ettei sellaista taidetta pitänyt julkisesti rahoittaa, joka ei markkinoilla pärjännyt omillaan. Baumolin ja Bowenin vastaus oli, ettei väestö voinut oppia nauttimaan taiteesta, jos sitä ei ollut ensin varaa esittää. Markkinoilla ilmenevä kulutuskysyntä ei muutenkaan kertonut koko totuutta ihmisten tarpeista, sillä toisilla oli enemmän varaa toteuttaa mielihalujaan kuin toisilla. (Mt., 379.)

Esittävän taiteen ongelmana oli siis riittävän rahoituksen puute. Huonolle tuottavuudelle nyt vain ei voinut mitään. Taidetta tai muutakaan palvelua, jossa lopputuotteena oli ihmisen aika ihmiselle, ei voinut tehostaa. Baumolin ja Bowenin teoksen esipuheessa säätiön johtaja August Hecksher toivoi, että teoksessa esitetyt luvut ja analyysi johtaisivat merkittävästi suurempiin taloudellisiin lisäpanostuksiin hallituksen taholta. Säätiön nettisivuilla kirjan esittelyn yhteydessä tätä toivotaan edelleen.

\section{Hyvinvointivaltion taudinkuva}

Suomalaisessa keskustelussa Baumolin tauti on yhä erittäin ajankohtainen käsite, mutta sangen toisessa merkityksessä. Tauti liitetään keskusteluun hyvinvointivaltion ja hyvinvointipalvelujen tulevaisuudesta. Palveluiden tuottavuuden todetaan kohoavan heikosti, aivan kuten Baumol ja Bowen esittivät. Ratkaisuksi ei kuitenkaan ole tapana esittää lisärahoitusta, vaan julkisen sektorin tuottavuuden parantamista. Sanotaan, että hyvinvointivaltioon ei ole varaa, ellei hyvinvointipalveluiden tuottavuus kasva. Kuluneen vuoden rakenneuudistuskeskustelussa ajatus on viety vielä pidemmälle: palveluihin ei ole varaa, ellei osaa niistä lakkauteta. Tämä oletettavasti uskotaan kasvattavan koko järjestelmän tuottavuutta (yksittäisen palvelun tuottavuutta ei tietenkään voida kasvattaa sitä lakkauttamalla: jos ei ole panoksia eikä suoritteita, ei ole tuottavuutta kuvaavaa suhdelukuakaan).

Baumol ja Bowen pitivät itse lähtökohtana, ettei sellaisten palveluiden tuottavuutta voi parantaa, missä lopputuotteena on ihmisen aika toiselle ihmiselle. Suomessa 1980-luvulla käynnistyneessä julkisen sektorin reformissa ja siihen liittyvissä tuottavuusohjelmien jatkumossa on kuitenkin uskottu toisin. Kunhan vain asetetaan tulostavoitteita, tuloksiakin syntyy. Vaikka siten, että yhdeltä työntekijältä vaaditaan yhä enemmän suoritteita. 
Palveluissa tämä tarkoittaa vähemmän aikaa ihmiseltä ihmiselle. Hyvinvointitavoitteen kannalta juuri tämä on ongelmallista, sillä hyvinvoinnin rakentaminen edellyttää nimenomaan onnistunutta vuorovaikutusta ihmisten välillä (Aaltio 2013). Jatkuva aikapaine uuvuttaa ja pakottaa työntekijöitä tinkimään ammatillisista laatuvaatimuksistaan (Hirvonen \& Husso 2012).

Sosiaalipoliittisesti voidaan pitää perusteltuna, että harjoitettu yhteiskuntapolitiikka mahdollistaisi hyvinvointipalvelujen järjestämisen ja tuotannon siinä laajuudessa ja sillä intensiteetillä, että hyvinvointierot pienenisivät ja väestön hyvinvointi kasvaisi - työntekijöiden työssäjaksaminen ja riittävä toimeentulo mukaan lukien. Paradoksaalisesti ne toimet, joilla hyvinvointivaltion tulevaisuus luvataan turvata, ovat leikkauksia, joilla nykyisinkin riittämättömäksi katsottavaa palvelutasoa entisestään heikennetään.

Palvelualan tuottavuutta lisättäessä Baumolin tauti yritetään kumota. Baumolin oma näkemys kuitenkin on, ettei hidas tuottavuuskehitys ole ongelma. Se saa palvelut ehkä näyttämään kalliilta, mutta tosiasiassa niihin on varaa. Ongelmana sen sijaan on tavaratuotannon nopea tuottavuuskehitys, jonka ansiosta meillä on yhä enemmän varaa ympäristön ja turvallisuuden kannalta kestämättömään kulutukseen.

\section{Se minkä yhteisö tuottaa, se yhteisöllä on varaa ostaa}

Esittävän taiteen ongelmia käsitelleen teoksen julkaisemisen jälkeen William Baumol sai käsinkirjoitetun viestin Joan Robinsonilta, Cambridgen yliopistossa jälkikeynesiläistä talousteoriaa luoneelta professorilta. Robinson halusi huomauttaa Baumolille, että vaikka tuottavuus kohosi toisaalla hitaammin, toisaalla nopeammin, se joka tapauksessa kohosi kaikkialla. Tästä määritelmällisesti seurasi, että ihmistyötä tarvittiin aiempaa vähemmän tuottamaan sama, tai suurempi, määrä tavaroita ja palveluja. Tämän seurauksena yhteiskunnalla itse asiassa oli varaa enemmän kaikkeen. Baumol jäi miettimään asiaa, ja pohdinnan tuloksena syntyi vuonna 2012 julkaistu teos "Cost disease. Why computers get cheaper and health care doesn't" (Yale University Press).

Tuossa teoksessa Baumolin kiinnostus on laajentunut taiteesta kaikkiin muihinkin yleishyödyllisiin, ja hyvinvoinnin kannalta tarpeellisiin palveluihin kuten terveydenhuoltoon, koulutukseen, jätehuoltoon, kirjastoihin 
ja poliisityöhön. Tuottavuus kehittyy yhä edelleen epätasaisesti eri aloilla. Hän jaksaa väsymättä toistaa, että palveluissa ihmistyövoiman hinta nousee juuri siksi, että tavaratuotannon tuottavuus nousee. Kustannusten nousu ei siis johdu siitä, että palveluita tuotettaisiin jotenkin väärin.

Baumol on huolissaan siitä, että epätasaisen kustannuskehityksen seurauksena ihmistyövoimaa on ryhdytty pitämään liian kalliina. Tämä, Baumol korostaa, on pelkkä illuusio. Tuottavuuden nousu tekee yhteiskunnasta (ainakin materiaalisessa mielessä) vauraamman, ei köyhempää. Kun joku kuluttaa dollarin, toinen tienaa sen. Kaikki, minkä yhteiskunta yhteensä kuluttaa, siirtyy tuloiksi saman yhteiskunnan sisällä. Näin ollen kaikkeen, mitä tuotetaan, on Baumolin mukaan aina varaa.

Ongelma liittyykin siihen, miten tulot ja kulutusmahdollisuudet yhteiskunnan jäsenten kesken jakautuvat. Koska tulonjako on epätasaista, yhteiskunnan on pidettävä huolta siitä, että tarpeelliset palvelut ovat myös pienituloisten käytössä. Baumol ei hyväksy tehostamisen ja säästöjen nimissä tehtyjä leikkauksia, jotka ovat johtaneet palvelujen laadun huononemiseen, jonojen pidentymiseen tai poiskäännyttämiseen. Hän ei usko yksityisen tuotannon parempaan tuottavuuteen. Heikko tuottavuuskehitys johtuu palvelutyön luonteesta, ei sen tuottajan omistuspohjasta. Ironista kyllä, juuri näitä Baumolin kritisoimia ratkaisuja on Suomessa tehty hyvinvointivaltion tulevaisuuden turvaamiseksi. Juuri Baumolin tautiin vedoten.

Baumol kirjoittaakin olevansa huolissaan siitä, etteivät poliitikot ymmärrä kustannustaudin luonnetta. He tekevät tarpeettomia leikkauksia, ja kasvattavat huono-osaisuutta. Palveluiden tulevaisuutta ei Baumolin mukaan turvata ripeyttämällä palveluiden tuottamista, vaan kohdistamalla alati kasvava ostovoimamme arvokkaina pitämiimme asioihin.

\section{Uusi diagnoosi: väärinymmärretty valtion velka}

Baumolin analyysi ei sellaisenaan vielä auta hyvinvointivaltion tulevaisuuden ratkomisessa. Baumol kyllä kannattaa julkisia tukia yhteiskunnan sivistystä, turvallisuutta, kulttuuria ja terveyttä edistäville palveluille. Hän myös kannattaa palveluiden tarjoamista niille, joilla palveluihin ei olisi itse varaa. Tällainen näkemys edustanee laajaa julkista vastuuta yhdysvaltalaisessa mittakaavassa. Pohjoismainen universaali hyvinvointivaltio on kuitenkin 
vielä laajempi julkinen sosiaaliturvajärjestelmä, jossa hyvinvointipalveluita tarjotaan koko väestölle - tuloihin katsomatta. Baumolin näkemys on, että julkiset palvelut rahoitetaan verovaroilla. Suomalaisen hyvinvointivaltion kannalta vastaus ei ole riittävä. Juuri käsitys siitä, että julkinen kulutus pitäisi pidemmällä tähtäimellä rahoittaa pelkillä verotuloilla, pakottaa poliitikot ikäviin leikkauksiin valtion budjetin tasapainottamiseksi.

Mitä hyvinvointivaltion tulevaisuudesta huolestuneen kansalaisen sitten tulisi ajatella? Palveluiden huono tuottavuus ei olekaan ongelma, vaan niiden syvin olemus. Mutta miten velkaantuvilla kunnilla ja valtiolla sitten on varaa palveluihin, jos ne vain kallistuvat, eikä tätä kehitystä tulisi edes estää?

Vastaus löytyy Baumolin maanmieheltä ja kollegalta, yhdysvaltalaiselta taloustieteilijältä Abba Lerneriltä. Edellä huomasimme, että Baumolin tautiin liittyy ikäviä väärinkäsityksiä. Julkiseen velkaan niitä liittyy vähintään yhtä paljon.

Lernerin lähtökohtana oli se havainto, että valuutta on valtion luomus (Lerner 1947). Valtiolla on oikeus paitsi verottaa, myös määrätä missä valuutassa verot on maksettava. Tämä määräysvalta antaa muutoin arvottomille paperinpalasille arvon, joka on yleisesti hyväksytty. Valtio voi laskea tätä valuuttaa liikkeelle haluamansa määrän ja käyttää sitä hankkiakseen hyödykkeitä ja palveluita yksityisiltä toimijoilta. Tästä seuraa, ettei valuutta ole valtion näkökulmasta koskaan niukka resurssi. Sen sijaan muille toimijoille se voi sitä ollakin, jos valtio ei laita sitä kiertoon - esimerkiksi investointien ja palkanmaksun muodossa.

Lernerin $^{i}$ näkökulmasta on siis absurdia väittää, ettei valtiolla olisi varaa kuluttaa. Verotuksen tehtävä on hillitä inflaatiota, tasata tuloja ja ohjata ihmisten kulutusta, esimerkiksi pois haitallisina pidetyistä kohteista. Vaikka veroja kerätäänkin, ja ne näkyvät valtion ja kuntien kirjanpidossa tuloina, ne eivät ole julkisyhteisöjen ainoa tulonlähde saati ajallisesti edes se ensimmäinen rahoituskanava. Käsitys siitä, että olisi talouden kannalta kestävää, tai moraalisesti hyveellistä, pitää valtion budjetti tasapainossa (eli kuluttaa vain verotuloja vastaava määrä) ei perustu modernissa rahatalousjärjestelmässä mihinkään välttämättömään tarpeeseen. Valtion velka on haitallista ainoastaan siinä tapauksessa, jos valtiota on poliittisesti estetty harjoittamasta omaa rahapolitiikkaansa ja rahoittamaan omaa kulutustaan keskuspankista. 
Valtavirtaisessa talousajattelussa toistuva huoli julkisen kulutuksen kasvusta ja valtion velkaantumisesta on ymmärrettävä tilanteessa, jossa Suomi on Euroopan talous- ja rahaliiton jäsenmaana riippuvainen Euroopan keskuspankin harjoittamasta rahapolitiikasta, sen halukkuudesta tukea jäsenvaltioiden finanssipolitiikkaa sekä yksityisistä rahoitusmarkkinoista, joilta valtio lainaa tarvitsemansa euroreservit. Näin ei tarvitsisi olla. Euroopan keskuspankki voisi toimia myös jäsenvaltioidensa viimekätisenä lainaajana, jolloin puhe valtion velan korosta ja luottoluokituksista voitaisiin kertaheitolla unohtaa. Kestävyysvajekin voitaisiin unohtaa, kun ymmärrettäisiin, ettei valtion tarvitse olla täysin velaton. Alijäämän ja velan määrä riippuisi kulloisestakin yhteiskunnallisesta tilanteesta: tarpeesta työllistää työttömiä tai tuottaa yhteiskunnallisesti arvokkaina pidettyjä palveluita.

Lernerin mukaan valtion harjoittamaa talouspolitiikkaa tulee arvioida ensisijaisesti sen seurausten - ei sille laadittujen sääntöjen noudattamisen kannalta. Suosittelemastaan talouspolitiikan arviointitavasta Lerner käytti termiä "funktionaalinen rahoitus" (Lerner 1943).

\section{Halvat tavarat tulevat ihmiskunnalle kalliiksi}

Lopuksi yhdistämme Abba Lernerin funktionaalisen rahoituksen Baumolin havaintoon siitä, että ihmistyötä edellyttävät palvelut kallistuvat aina niin kauan, kuin tavaratuotannon tuottavuus nousee. Palveluiden tuottavuutta ei voi mainittavasti parantaa, koska palveluissa on kyse ihmisten välisestä vuorovaikutuksesta. Tätä ei voi tehostaa eikä korvata koneella ilman, että palvelun laatu heikkenee.

Lopputuloksena on, että arvostamiemme julkisten palvelujen tuottaminen tulee kalliimmaksi. Lernerin sanoma on, että tähän meillä on varaa - jos niin haluamme. Meidän pitää poistaa itse rakentamiamme julkisen kulutuksen rahoitusrajoitteita.

Baumolin taudista voidaan loogisesti johtaa myös tämä havainto: jos haluamme kaventaa palveluiden ja tavaratuotannon tuottavuuskuilua, meidän pitäisi palata hitaaseen tavaratuotantoon. Mitä enemmän tavaran ja ruoan tuotannossa tarvitaan ihmistyövoimaa, sitä kalliimmaksi niiden tuottaminen muuttuu. Ero palvelutuotannon kustannuksiin kapenee. Kustannustauti selätetty! 
Jos finanssipolitiikka järjestettäisiin Lernerin oppien mukaisesti, eri sektoreiden välinen tuottavuuskuilu ja palveluiden kalleus eivät aiheuttaisi rahoituksellista ongelmaa. Jatkuva tuottavuuskasvu synnyttää kuitenkin muunlaisia ongelmia. Vuonna 2012 Baumol kirjoittaa, että hänen nimiinsä laitetun taudin huolestuttavin seuraus ei ole kallistuvat palvelut, vaan alati halpenevat tavarat. Tuottavuuden nopea kehitys tavaratuotannossa uhkaa hyvinvointiamme. Se on johtanut paitsi halvempiin autoihin, myös halvempiin joukkotuhoaseisiin. Se on lisännyt liikenneruuhkia, terrorismin uhkaa, kertakäyttökulutusta ja jätteiden määrää. Massatuotanto on johtanut ympäristön turmelemiseen ja ilmastonmuutokseen.

Baumolin tauti on todellakin tauti, mutta täysin eri merkityksessä kuin se yleensä ymmärretään.

\section{Kirjallisuus}

Aaltio, Elina. 2013. Hyvinvoinnin uusi järjestys. Helsinki: Gaudeamus.

Baumol, William J. \& Bowen, William G.. 1966. Performing arts - the economic dilemma. A study of problems common to theater, opera, music and dance. New York: The Twentieth Century Foundation.

Baumol, William J. 2012. Cost disease. Why computers get cheaper and health care doesn't. New Haven, CT: Yale University Press.

Hirvonen, Helena \& Husso, Marita. 2012. Hoivatyön ajalliset kehykset ja rytmiristiriidat. Työelämän tutkimus, 10:2, 119-133.

Lerner, Abba. 1943. Functional finance and the federal debt. Social Research, 10, $38-51$.

Lerner, Abba. 1947. Money as a creature of the state. American Economic Review, $37: 2,312-317$.

\section{Viitteet}

I) Lernerin työtä ovat jatkaneet monet chartalistit, esimerkiksi L. Randall Wray. 